\section{The effect of the reproductive cycle on the bioaccumulation of heavy metals and the induction of metallothionein in the polychaete Perinereis cultrifera of the coastline of El Jadida (Atlantic coast, Morocco)}

\author{
A. Rouhi, ${ }^{1}$ J. Sif, ${ }^{2}$ Y. Elyadari ${ }^{2}$ \\ ${ }^{1}$ Centre Régional des Métiers de \\ l'Education et de la Formation, Beni \\ Mellal; 'Équipe de Physiologie et \\ d'Écotoxicologie, Université Chouaib \\ Doukkali, Faculté des Sciences, EI Jadida, \\ Morocco
}

\section{Introduction}

The Annelid Polychaetes are the important representatives of the benthic community recognized as biological tools of choice to reveal the perturbations which affect coastal ecosystems. ${ }^{1}$ The bioaccumulation of trace metals and their harmfulness was studied in different marine species. The detoxification of metals involves their liaison with different ligands, in order to limit their bioavailability and therefore their deleterious effects. ${ }^{2}$ The induction of metallothionein-like proteins (MTLP) by the metals in these living organisms, plays a crucial role in their regulation and $\mathrm{a}$ in their mechanism of detoxification. ${ }^{3}$

Perinereis cultrifera (Grube, 1840) is a Polychaete present along the Atlantic coast of El Jadida. Their repartition, reproduction and population dynamics have been studied by our team. ${ }^{4,5}$ The present work has therefore the objective to investigate to what extent the induction of MTLP by the bioaccumulation of trace elements is influenced by the reproductive cycle of the Polychaete $P$. cultrifera. This species was sampled in the epitokous (abrupt changes in the body structure of many worms of the class Polychaeta. The epitokous occurs in the period of sexual reproduction, when the worms become adapted to swimming) and atokous forms, which represents another reason for our choice of this study.

\section{Materials and Methods}

Samples of $P$. cultrifera were collected seasonally during 2004 in the intertidal zone at low tide, from two sites (Figure 1). The SM site (Mouilha Site) is located in the immediate vicinity of an urban sewage, and the SR site is located $10 \mathrm{~km}$ from the first. On our arrival to the laboratory, the animals were placed in the seawater after being filtered by flirted-paper and oxygenated for a purge period of $24 \mathrm{~h}$.

Analysis of cadmium (Cd), zinc (Zn) and copper $(\mathrm{Cu})$ is carried out on the samples of the worms dried in the oven. Digestion (with nitric acid) was done during $1 \mathrm{~h}$ with room temperature, and to $140^{\circ} \mathrm{C}$ in a sand bath for 3 h. The acid solutions thus obtained are filtered (flirted-paper) and analyzed by atomic absorption spectrophotometry (AAS). On the other hand, worms were homogenized in $20 \mathrm{mM}$ TRIS, $150 \mathrm{mM} \mathrm{NaCl}$ solution adjusted to $\mathrm{pH}=8.6$. The homogenate obtained was subject to the protocol of compartmentation: ${ }^{6}$ the soluble and insoluble fractions were separated by centrifugation ( $25,000 \mathrm{Xg}$ for $55 \mathrm{~min}$ ). The soluble heat-stable thiolic compounds (MTLP) were isolated by centrifugation of the soluble fraction $(15,000 \mathrm{X} \mathrm{g}$ for $10 \mathrm{~min})$ after heattreatment $\left(75^{\circ} \mathrm{C}\right.$ for $\left.15 \mathrm{~min}\right)$. The quantification of (MTLP) is done in the cytosolic fraction by differential pulse polarographic analysis (PAR Model 174 analyzer, PAR/EG\&G Model 303 static mercury drop electrode).

The stage of sexual maturity of $P$. cultrifera is evaluated by the measurement of the average diameter of the oocyte, using a nearest micrometer (30 oocytes/female). For each oocyte, the diameter is estimated by the sum of the maximum and minimum length. In order to estimate the number and age distribution of the cohorts at a given season, seasonal measurements of fresh weight were also carried out for the entire population of SM. ${ }^{4}$ The analysis of variance (ANOVA) and the test of NewmanKeuls have been used for expressing and comparing the results.

\section{Results and discussion}

In specimen tissues of $P$. cultrifera from the station SR, the total levels of Cd was highly variable. The minimum and maximum content is 0.087 and 0.719 g. $\mathrm{g}^{-1}$ respectively in autumn and summer (Figure 2). The quantity in $\mathrm{Zn}$ is $35.317 \mu \mathrm{g} . \mathrm{g}^{-1}$ in autumn while that of $\mathrm{Cu}$ shows no significant difference according to the seasons. For the animals of the station SM, the highest concentrations of $\mathrm{Cd}, \mathrm{Zn}$ and $\mathrm{Cu}$ were $0.155 ; 65.5$ and 2.807 g.g $^{-1}$ in winter.

The quantification of MTLP shows that their concentration is highly significant in the spring in worms of SM, which is $940 \mu \mathrm{gg} \cdot \mathrm{g}^{-1}$. The lowest value is $428 \mu \mathrm{g}_{\mathrm{g}} \mathrm{g}^{-1}$ in summer (Figure 3). The highest rate for worms of SR is $859 \mu \mathrm{gg} . \mathrm{g}^{-1}$ in winter.

The maximum induction of MTLP observed in worms of SM coincided with the oocyte diameter (Figure 4). The two parameters show
Correspondence: Jamila Sif, Équipe de Physiologie et d'Écotoxicologie, Université Chouaib Doukkali, Faculté des Sciences, El Jadida, Morocco.

E-mail: sif.jamila16@yahoo.com

Key words: Perinereis cultrifera; heavy metals; reproductive cycle.

Conference presentation: part of this paper was presented at ECOBIM meeting, 2016 May-June, Le Havre, France.

This work is licensed under a Creative Commons Attribution NonCommercial 4.0 License (CC BYNC 4.0).

(C) Copyright A. Rouhi et al., 2016

Licensee PAGEPress, Italy

Journal of Xenobiotics 2016; 6:6588

doi:10.4081/xeno.2016.6588

a significant positive correlation $(\mathrm{r}=0.73$; $\mathrm{P}<0.05)$ and a very clear seasonal variation. In effect, the highest oocyte diameter is $316 \mu \mathrm{m}$ noted in the spring, and $940 \mu \mathrm{g}^{-\mathrm{g}^{-1}}$ for the MTLP of animals (Figure 3). This profile follows a gradual evolution from summer to spring. The evolution of the population of $P$. cultrifera, reprsented by frequency histograms of weight during the four seasons, shows that the structure of the population is normal and unimodal, except in the spring. The population is formed by three cohorts ( $\mathrm{C} 1, \mathrm{C} 2$ and $\mathrm{C} 3$ ) where the first corresponds to least aged individuals, the second to those who are older and the third represents the youngest specimens of the new generation. The measurement of the fresh weight means of cohorts showed a progressive increase from summer to spring, respectively, $\quad 13.51 \pm 4.68 \quad$ g. $10^{-2}$ and $42.28 \pm 12.64$ g. $10^{-2}$. This situation allows to say that P.cultrifera passes from a young population of medium size and moderately sip of genital products in the summer, to a population perfectly mature in the spring.

In the light of these results, the sexual maturity of $P$. cultrifera deriving from SM is highest in spring (old population and oocytes perfectly mature). In parallel, the concentration of MTLP follows almost the same time profile, this relationship seems to indicate that the reproductive cycle of these animals influences induction of MTLP. Therefore, two hypotheses are suggested: the first assumes that the MTLP induced would be due to the bioavailability of heavy metals, and the second, MTLP vary between the period of reproduction (oogenesis) and periods of sexual rest. ${ }^{7}$ Among these metals which induce strongly the synthesis of MTLP, Cd and $\mathrm{Zn} .{ }^{8}$ Seasonal variation of their tissue levels has already been suggested by several authors, as well as for the bivalves and for the polychaete. ${ }^{9}$ The second hypothesis 


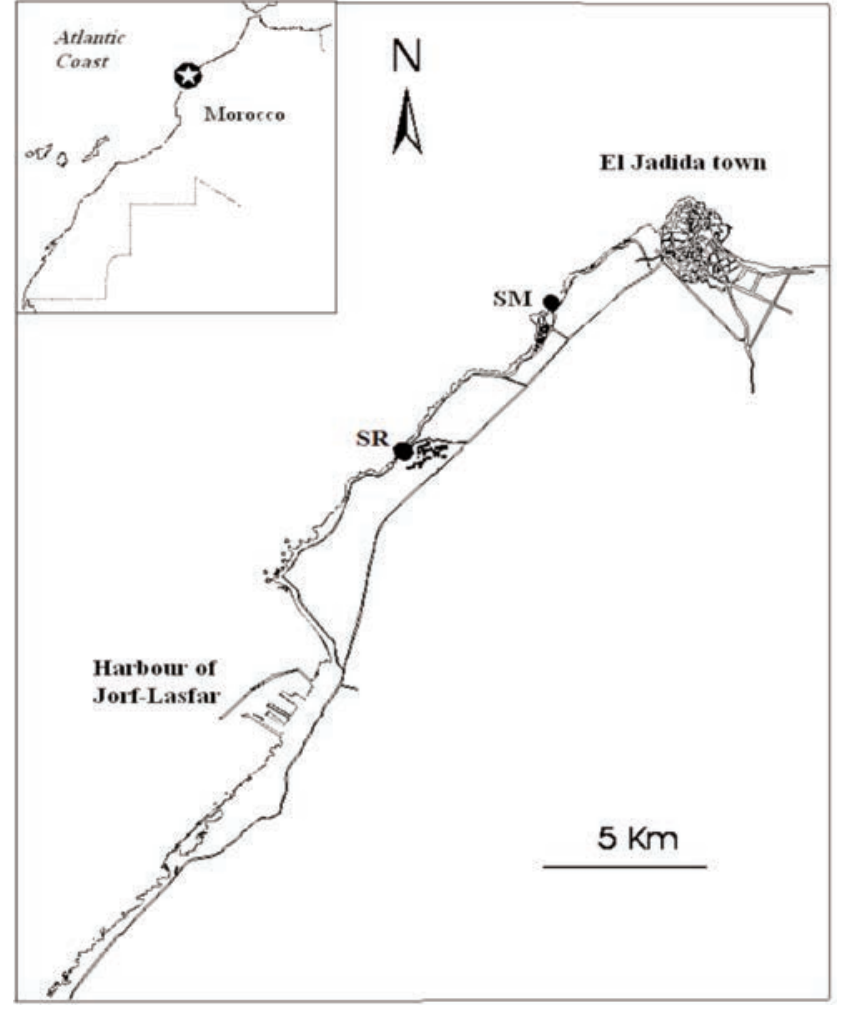

Figure 1. Location of the two sampling sites of Perinereis cultrifera, Morocco.

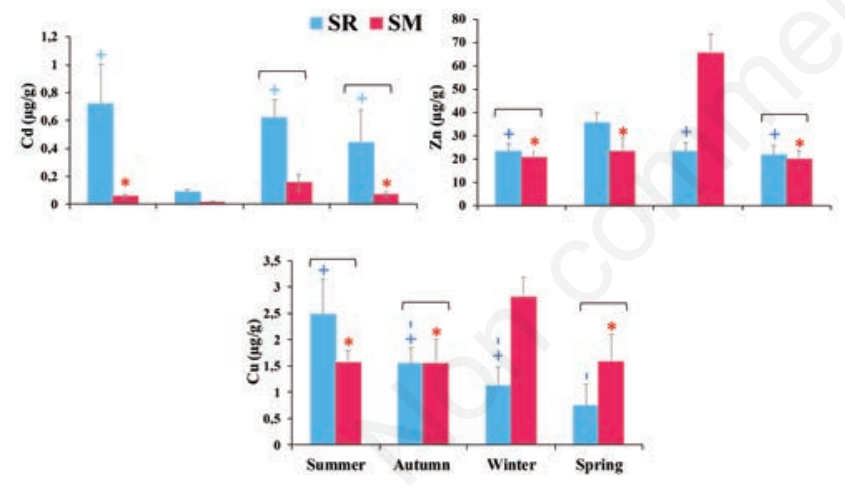

Figure 2. Seasonal variation of the concentration cadmium, zinc and copper in the $P$. cultrifera. $(+/-)$ Meaning $P<0.05$ between seasons of $\mathrm{SR}$; $\left(^{*}\right)$ Significance $\mathrm{P}<0.05$ between seasons of $\mathrm{SM}$; (bar) significance $P<0.05$ between $S R$ and $S M$.

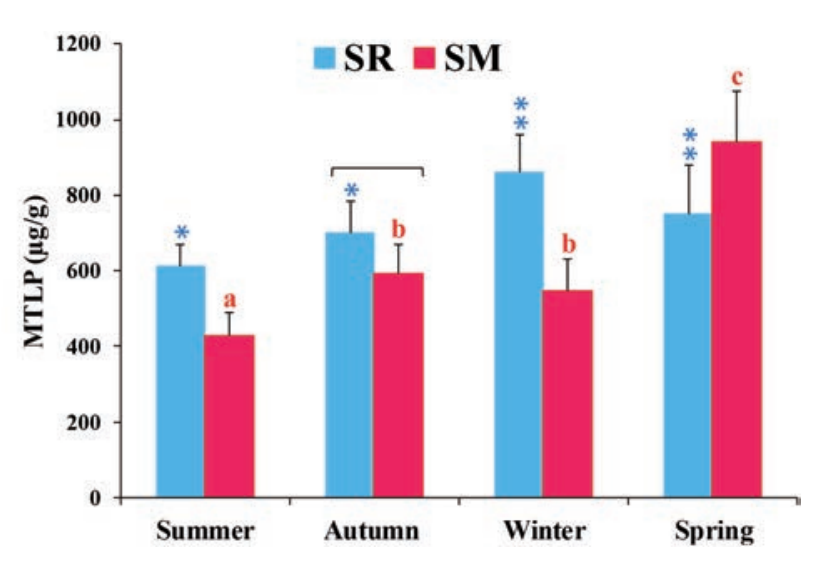

Figure 3. Seasonal evolution of metallothionein-like proteins (MTLP) in the polychaete $\boldsymbol{P}$. cultrifera. $(* / * *)$ Meaning $\mathbf{P}<\mathbf{0 . 0 5}$ between seasons of SR; (same letter) significance $P<0.05$ between seasons of SM; (bar) significance $P<0.05$ between SR and SM.

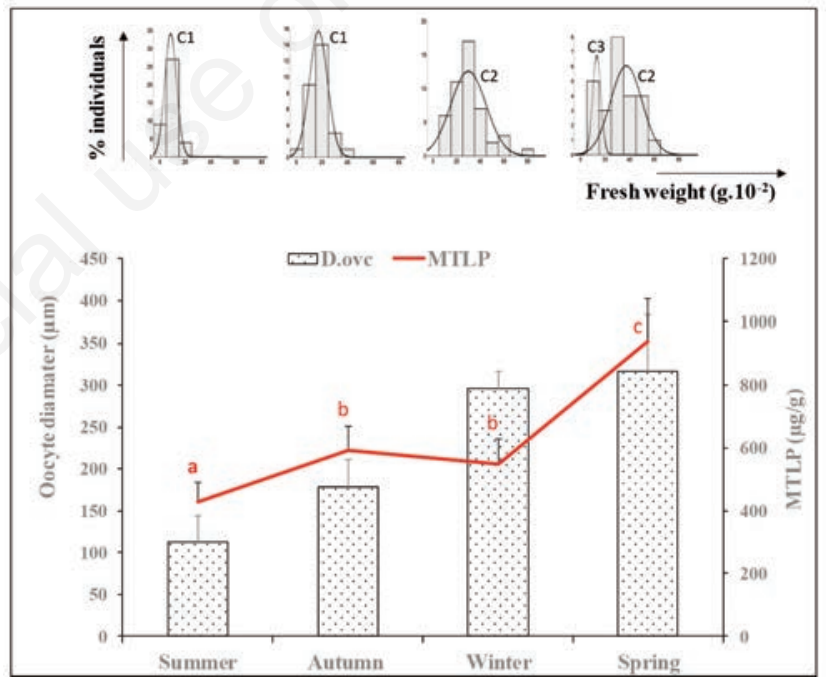

Figure 4. Seasonal evolution of frequency histograms of weight, oocyte diameter and MTLP concentration in the atokous form of P. cultrifera in $\mathrm{SM}$ station. $\left(\mathrm{C}_{1}\right.$ : Cohort $1 ; \mathrm{C}_{2}$ : Cohort 2 and $\mathrm{C}_{3}$ : Cohort 3). suggests that during the course of the sexual maturation, the mechanisms of vitellogenesis require the intervention of a number of hormones (steroid hormones and others) and/or enzymes which will be activated by the metallic elements, consequently leading to the induction of MTLP. Contrary to what is observed in Mya arenaria (Molluscan shellfish) ${ }^{10}$, the bivalve reproductive cycle (vitellogenesis and spawning) can modulate the expression of several biomarkers. In this situ- ation, MT levels are lower to increase the availability of metals that are found in egg yolk proteins.

\section{Conclusions}

In conclusion, the $\mathrm{Cd}$ and consequently the MTLP are changed during seasons. The animals of the station SR are the most contami- nated. In worms of the SM site, the highest rates are observed in winter and spring which coincide with the potential maturation of individuals.

\section{References}

1. Le Bris H, Glémarec M. Marine and brackish ecosystems of south Brittany (Lorient 
and Vilaine Bays) with particular reference to the effect of the turbidity maxima. Estuar Coast Shelf Sci 1996;42:737-53.

2. Mason AZ, Jenkins KD. Metal detoxication in aquatic organisms. In: Tessier A, Turner DR, eds. Metal speciation and biovailability in aquatic systems, vol. 3. Chichester: Wiley \& Sons; 1995. pp 469-608.

3. Walker CH, Hopkin SP, Sibly RM, Peakal DB. Principle of ecotoxicology. London: Taylor and Francis; 1996.

4. Rouhi A, Sif J, Fersiwi A, Gillet P, Deutch B. Reproduction and population dynamics of Perinereis cultrifera (Polychaeta: Nereididae) of the Atlantic coast, El Jadida, Morocco. Cah Biol 2008;49:151-
216.

5. Sif J, Rouhi A, Gillet P, Moncef M. Diversité et écologie des Annélides Polychètes du littoral atlantique de la région d'El Jadida, Maroc. Bul Inst Sci, Rabat, section Sciences de la Vie 2012;34:95-106.

6. Amiard-Triquet C, Caurant F. Les formes physicochimiques de stockage des métaux chez les organismes marins. Analusis 1994;22:24-6.

7. Viarengo A, Nott JA. Mechanisms of heavy metal cation homeostasis in marine invertebrates. Comp Biochem Physiol 1993;140C:355-72.

8. Geffard A, Amiard-Triquet C, Amiard JC, Mouneyrac C. Temporal variations of met- allothionein and metal concentrations in the digestive gland of oysters Crassostrea gigas from a clean and a metal-rich sites. Biomarkers 2001;6:91-107.

9. Regoli F, Orlando E. Mytillus galloprovincialis as a bioindicator of lead pollution: Biological variable variables and cellular responses. Sci Total Environ 1993;2:128392.

10. Blaise C, Gagné F, Pellerin J, Hansen PD, Trottier S. Molluscan shellfish biomarker study of the Quebec, Canada, Saguenay fjord with the softshell clam Mya arenaria. Environ Toxicol 2002;17:170-86. 